\title{
Internalization of Intellectual Capital Model Conception of SMES for MSME Entrepreneurs
}

\author{
Sulastri ${ }^{1}$, Yuki Fitria ${ }^{2 *}$, Chichi Andriani ${ }^{3}$ \\ 1, 2, ${ }^{3}$ Faculty of Economics, Universitas Negeri Padang, Padang, Indonesia \\ ${ }^{*}$ Corresponding author. Email: yukifitria@fe.unp.ac.id
}

\begin{abstract}
The purpose of this research is to internalize and increase knowledge of intellectual capital to SME actors in the city of Padang. The population in this study were all SMEs under the guidance of the Department of Cooperatives and UMKM in the city of Padang. The sample was determined through a purposive technique, so that the sample amounted to 40 people. At the first stage, respondents will be given a preliminary questionnaire to measure how well the respondent's understanding of the concept of intellectual capital models for SME actors is. Then the respondent will be given an intellectual capital module which is expected to help participants to understand and implement intellectual capital in their business and it is also hoped that there will be responses and criticisms from the respondents. So after the data was collected with the conditions before and after giving the module, then the data were analyzed through a different test with the ANOVA technique. From the research results, it was found that there were differences in the knowledge of respondents before and after giving the module significantly.
\end{abstract}

Keywords: Intellectual capital, Human capital, Customer capital, Structural capital.

\section{INTRODUCTION}

Multinational companies are able to dominate the world economy due to the implementation of intellectual capital in creating wealth [1]. Then, it is necessary to shift the perspective in running a company which is usually based on the role of financial capital into knowledge based. This matter will certainly turns the company into a more effective one in achieving its goals and to be competitive to face the globalization. According to the opinion of [2], the implementation of intellectual capital can be a competitive advantage for organizations.

In this decade there has been an increase in research related to intellectual capital. Likewise, [3] conducted research aiming as a preliminary study to develop items and constructs to empirically measure intellectual capital. Based on the result of the research, intellectual capital is classified into three dimensions which are described by 53 sub-dimensions. In line with [4] conducted a study; An Evidence-Based Taxonomy of Intellectual Capital. Based on the responses of respondents through questionnaires, 46 items were formulated to be used to measure the three dimensions of intellectual capital in an organization.
Basically, intellectual capital is implemented by all types of companies, including Micro, Small and Medium Enterprises (MSMEs). From the results of research by [5], it is known that intellectual capital in SMEs can contribute to the product innovation process which leads to increased performance of MSME. In line with [6], in general, intellectual capital has a positive impact on the performance of MSME. Then, it is necessary to formulate whether the items of intellectual capital that have been formulated in previous researches can be used to measure intellectual capital in MSMEs.

In order to answer this challenge, [7] conducted research using items of intellectual capital found in the research of [4] and [3]. This study aims to classify items that are expected to be implemented in better measuring the intellectual property of SMEs companies, especially in the city of Padang. Accordingly, through Factor Analysis, it is known that for the human capital dimension, only 7 items can properly measure human capital in MSMEs. Furthermore, there are 3 statement items which can be used to measure the dimensions of customer capital in SMEs. Lastly, for the structural capital dimension, there are 12 statement items considered important by SMEs entrepreneurs. Therefore, there are 22 items in total forming the intellectual capital model for MSMEs in Padang City. 
However, in reality, not all MSMEs in Padang City understand and implement intellectual capital in running their business. Basically, MSMEs entrepreneur in Padang City have not internalized the concept of intellectual capital in their business, this is presumably due to the limited knowledge and understanding of Padang City MSMEs players regarding the concept of intellectual capital. As the characteristics of MSMEs which are limited in the number of assets impacted the limitedness of the ability to hire employees with qualified competencies. As with MSMEs in the city of Padang, the majority of their employees' education levels are only senior high school (SMA/SMK) with limited experience and abilities. Competence is defined as basic characteristics that can be linked to the increasing of performance both individually and in teams, consists of knowledge, skill, and ability, [8].

Various studies have proven that knowledge has an effect on organizational performance, as in research of Wahyu, et al[9], stated that employee knowledge is the variable that has the most significant influence on employee performance. Then, [10] research also states that the knowledge possessed by employees has an effect on employee performance. Knowledge according to [11] is information that a person has for a particular field. Furthermore [12] stated that knowledge refers to factual or procedural information needed to successfully carry out a task. Knowledge includes educational
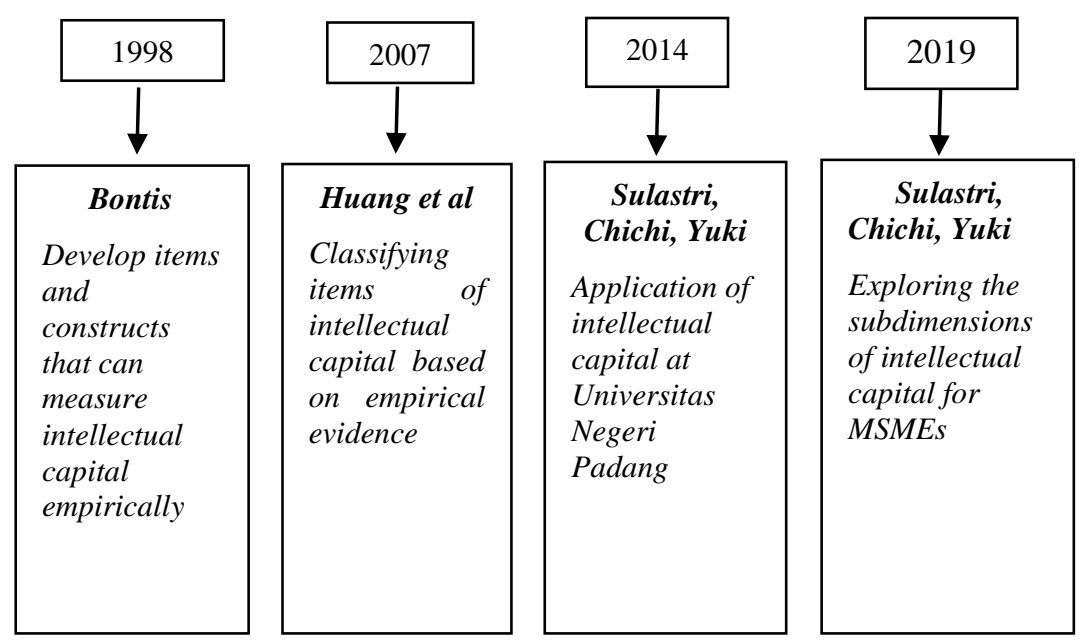

Figure 1 Intellectual capital research roadmap

Figure 1 above presents some of the previous research as the literature basis in this study. As is the case with the research conducted by [3] with the title Intellectual capital: an exploratory study that develops measures and models. This research becomes the basic literature to develop items and constructs to measure intellectual capital empirically. Therefore, from the research results, intellectual capital can be classified into three dimensions which are described by 53 sub-
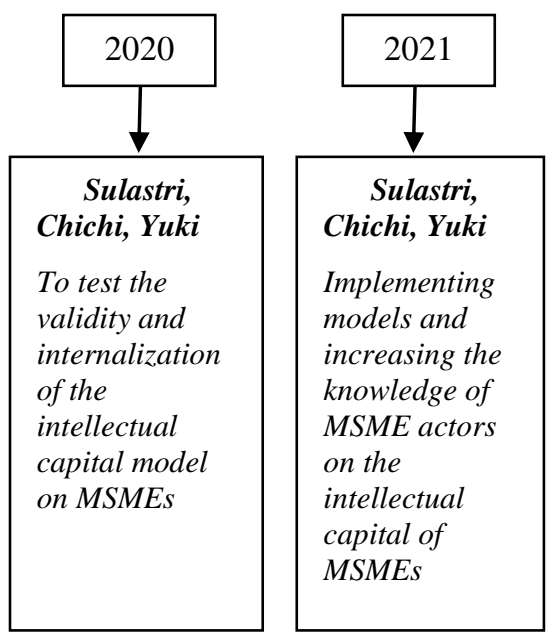

background and is supported by work experience, as well as knowledge of company management. Knowledge is a complex competence and is a crucial domain in shaping one's actions (Overt behavior). The results of the research proved that behavior based on knowledge will be imperishable than behavior which is not based on knowledge, since the knowledge owned will help in improving performance through the completion of each task, [11].

Therefore, the objectives of this study are; 1). Deploy or disseminate the intellectual capital taxonomic model of MSMEs to MSME entrepreneur in Padang City. 2) Internalize and increase knowledge pertaining to the concept of intellectual capital of MSMEs to MSME entrepreneur in Padang City.

The study of intellectual capital has been conducted for a long time and is an evolution in HRM science. The studies of Roos and Roos to Nick Bontis made a very strong contribution to the conception of intellectual capital, where the concepts and models for measuring intellectual capital from various previous research results can be applied by many companies and organizations. Even the previous research team has also conducted research on the implementation of intellectual capital, especially in universities. Figure 1 below shows the studies that have been carried out to examine the concept and measurement model of intellectual capital.
Sulastri,

plementin increasing the knowledge of MSME actors capital of MSME dimensions. Furthermore, there is also research conducted by [13] referring to [3] who conducted research on intellectual capital in the form of a dissertation, measuring intellectual capital (human capital, structural capital and customer capital) at gopublic manufacturing companies on the BEJ using the Human Resources Accounting (HRA) approach. Relevant to [4] also conducted research with the title; An Evidance-Based Taxonomy of Intellectual Capital. 
This study aims at classifying items of intellectual capital based on empirical evidence by distributing questionnaires to get responses from companies' managers.

Apart from research related to the exploration of the dimensions and sub-dimensions of intellectual capital, there are also several researches on the implementation of intellectual capital in MSME, like [5] research which links intellectual capital and innovation to the performance of MSME in Malaysia. Furthermore, [6] noticed the implications of intellectual capital on Mexican MSME based on the perspective of dynamic resources and capabilities. The result of [6] research showing the difference of sub-dimensions of intellectual capital in each industry, company or business. Finally, [14] has conducted research related to the application of intellectual capital at Padang State University.

\subsection{Characteristics of Intellectual Capital}

Before implementing intellectual capital in an organization, it is necessary to understand what is meant by intellectual capital. There are several experts defined of the intellectual capital. Among them are the definitions put forward by [15] saying that the term intellectual capital is used for all non-tangible or nonphysical assets and resources of an organization, including processes, innovation capacity, patterns and invisible knowledge of its members and collaboration networks as well as organizational relationship. Meanwhile, as quoted by [16], he equates intellectual capital as the amount of human capital and structural capital.
Referring to the definition above, it can be concluded that intellectual capital as the sum of what is produced by the three main elements of the organization (human capital, structural capital, customer capital) related with knowledge and technology providing added value to the company for competitive advantage.

Combination of intangible resources includes various resources of knowledge, experience, and expertise related to employee expertise, good relationships with customers, and the company's information technology capacity which significantly contribute to the value creation process providing a competitive advantage for the company. As according to [17] the use of intellectual property as a process and tool should is required to generate economic added value in the form of organizational performance.

\subsection{Taxonomy of Intellectual Capital Dimensions}

[3] identify that three main constructs of IC, that is human capital (HC), structural capital (SC) and relational capital (RC). Through empirical research, [3] explored and developed items from each of the main constructs of IC, in order to obtain 53 items.

[4] also mentioned that in intellectual capital lies three dimensions, that is human capital, structural capital and relational/customer capital. Furthermore, [4] conducted research aimed at classifying items of intellectual capital. From the results of this study, 46 items were found to be used to measure intellectual property in a company, as shown in table 1 below;

Table 1. Taxonomy of intellectual capital

\begin{tabular}{|l|l|}
\hline Dimensions IC & \\
\hline \multirow{3}{*}{ Human capital } & HC1 Employees' know-how/expertise \\
& HC2 Employees' level of education/vocational qualification \\
& HC3 Employees' work-related competence \\
& HC4 Employees' creativity/innovativeness \\
& HC5 Employees' work-related knowledge \\
& HC6 Employees' job satisfaction \\
& HC7 Key employee turnover \\
& HC8 Leadership qualities of managers \\
& HC9 Employees' training \\
& HC10 Employees' profitability (e.g. revenue per employee, etc.) \\
& HC11 Incentive programme/compensation scheme \\
& HC12 Employees' previous job experiences \\
& HC13 Employees' motivation \\
& HC14 Employees' loyalty \\
& HC15 Employee recruitment costs \\
\hline
\end{tabular}




\begin{tabular}{|c|c|}
\hline Structural capital & $\begin{array}{l}\text { SC1 Exploitation and management of patents, copyrights and trademarks } \\
\text { SC2 Organisational culture in written form } \\
\text { SC3 IT systems and their usage in your company } \\
\text { SC4 Networking systems with customers, suppliers, databases, etc. } \\
\text { SC5 Management (including financial) control system } \\
\text { SC6 Internal communication system } \\
\text { SC7 Documentation of knowledge in manuals, databases, etc. } \\
\text { SC8 Data systems providing access to relevant information } \\
\text { SC9 Execution of corporate strategies } \\
\text { SC10 Effectiveness of expenditure on R\&D } \\
\text { SC11 Development of new ideas/products/services } \\
\text { SC12 Implementations of new ideas/products/services } \\
\text { SC13 Length of time for product design/product development } \\
\text { SC14 Quality of product/service supplied } \\
\text { SC15 Life-cycles of products } \\
\text { SC16 Society's image of the company }\end{array}$ \\
\hline Customer capital & $\begin{array}{l}\text { CC1 Market demands for products/services } \\
\text { CC2 Customers' loyalty to your company/product e.g. repeat sales } \\
\text { CC3 Company's distribution channels allowing customers access to products/services } \\
\text { CC4 Opportunities for business alliances/partnerships/ collaborations } \\
\text { CC5 Opportunities for licensing/franchising agreements } \\
\text { CC6 Favourable contracts obtained due to company's unique position } \\
\text { CC7 Customers' satisfaction (e.g. via survey) with company/product } \\
\text { CC8 Timeliness of product/service delivery } \\
\text { CC9 Customer complaints and responses to complaints } \\
\text { CC10 Customer acquisitions (new customers) } \\
\text { CC11 Customer profitability } \\
\text { CC12 Market share } \\
\text { CC13 Growth in business or service volume } \\
\text { CC14 Dependence on key customers } \\
\text { CC15 Updated customer list/profile }\end{array}$ \\
\hline
\end{tabular}

Source: [4]

Based on table 1 above, it can be seen that there are 15 sub-dimensions for measuring the dimensions of human capital, 16 sub-dimensions for measuring the dimensions of structural capital and 15 sub-dimensions for measuring the dimensions of customer capital.

[7] conducted a study which was a replica of [4]. This study is the first year of a two-year research plan. By using items of intellectual capital found in the research of [4] and [3], a factor analysis was carried out to group these items which are expected to be implemented in better measuring the intellectual property of MSMEs companies, especially in Padang City. The results of the research is summarized in table 2 below:

Table 2. Taxonomy of intellectual capital items for MSMEs

\begin{tabular}{|l|l|l|}
\hline \multicolumn{1}{|c|}{$\begin{array}{c}\text { Human } \\
\text { Capital }\end{array}$} & \multicolumn{1}{c|}{$\begin{array}{c}\text { Customer } \\
\text { Capital }\end{array}$} & Structural Capital \\
\hline $\begin{array}{l}\text { Employees } \\
\text { training }\end{array}$ & $\begin{array}{l}\text { Consumer } \\
\text { satisfaction on } \\
\text { company's products } \\
\text { / services }\end{array}$ & $\begin{array}{l}\text { Employees share } \\
\text { knowledge within the } \\
\text { company }\end{array}$ \\
\hline
\end{tabular}

\begin{tabular}{|c|c|c|}
\hline $\begin{array}{l}\text { Employees } \\
\text { recruitment costs }\end{array}$ & $\begin{array}{l}\text { Understanding of } \\
\text { consumer needs }\end{array}$ & $\begin{array}{l}\text { IT systems used by } \\
\text { companies }\end{array}$ \\
\hline $\begin{array}{l}\text { Employees } \\
\text { competence } \\
\text { related to } \\
\text { productivity }\end{array}$ & $\begin{array}{l}\text { Fulfillment of } \\
\text { consumer needs } \\
\text { and desires }\end{array}$ & $\begin{array}{l}\text { Increasing the quality of } \\
\text { products/ services }\end{array}$ \\
\hline $\begin{array}{l}\text { Employees } \\
\text { education level } \\
\text { according to job }\end{array}$ & & $\begin{array}{l}\text { Improving the quality } \\
\text { of products and services }\end{array}$ \\
\hline Teamwork & & $\begin{array}{l}\text { Quality of product or } \\
\text { service }\end{array}$ \\
\hline $\begin{array}{l}\text { Employees work } \\
\text { motivation level }\end{array}$ & & $\begin{array}{l}\text { Increase in company's } \\
\text { income }\end{array}$ \\
\hline \multirow[t]{6}{*}{$\begin{array}{l}\text { Employees } \\
\text { loyalty }\end{array}$} & & $\begin{array}{l}\text { Implementation of new } \\
\text { ideas of products / } \\
\text { services }\end{array}$ \\
\hline & & $\begin{array}{l}\text { Support for employee } \\
\text { creativity }\end{array}$ \\
\hline & & Ease of system \\
\hline & & $\begin{array}{l}\text { Consideration of } \\
\text { implementing new } \\
\text { product/service ideas }\end{array}$ \\
\hline & & $\begin{array}{l}\text { Increase in company } \\
\text { turnover }\end{array}$ \\
\hline & & Business prospect \\
\hline
\end{tabular}

Source: [7] 
Based on Table 2 above, it is discovered that for the human capital dimension of the 8 statement items, only 7 items could properly measure human capital in MSMEs. Furthermore, from the 8 statement items for the customer capital dimension, only 3 statement items to well measure the dimensions of customer capital in MSMEs, which are related to the level of consumer satisfaction on company's products/services, the level of understanding and the company's ability to meet consumer needs and desires. Finally, for the structural capital dimension, initially there were 13 statement items, yet only 12 statement items were considered substantial by MSME entrepreneurs to measure the structural dimensions of their business capital. Hence, there are 22 items in total configuring the intellectual capital model for MSMEs in Padang City.

Human capital represented by the knowledge and skills possessed by employees individually or personally. When employees exit or leave the company, the knowledge and skills will also leave the company. Therefore, retaining employees is an important factor for the company to run its operations swiftly. Referring to the research results of [7], the sub-indicators that are relatively important for the dimensions of human capital in MSME, especially in the city of Padang are: employee training, recruitment costs, competence in production, education level, teamwork, employees' motivation and employee loyalty.

Refers to a mechanism and structure owned by the organization, employees could optimally elaborate their individual human capital, in order to achieve high individual work performance as an effort to achieve the best organizational performance [18]. Therefore, structural capital is generally mentioned as the infrastructure owned by the company allowing the company to function optimally and to adapt to any changes occurred. Based on the research results of [7] the relatively crucial sub indicator for the dimension of human capital in MSMEs in the city of Padang are; employees share knowledge within the company, the use of IT system in the company, increasing the quality of products/services as well as improving them, maintaining the quality of product or service, increasing the company revenue, implementing new ideas on products or services, supporting employee creativity, system convenience, consideration of implementing new product/service ideas, increasing company turnover and business prospects.

Customer capital refers to the company's strength to succeed that lies in the hands of consumers, which the company need to be able to accumulate, maintain and create. Costomer capital is manifested in the form of a partnership characterized by a long-term perspective, determination, honesty, accuracy, flexibility, and tolerance, [19]. Consumers are a guarantee of the company's cash flow in the future and will determine the sustainability of the business or company. As for the relatively crucial sub-indicators for the dimension of human capital in MSME in the city of Padang are [7]; customer satisfaction, understanding and meeting the consumer needs.

\section{METHOD}

The objectives of this study are; to socialize, internalize and increase the knowledge of intellectual capital to MSMEs entrepreneurs in Padang City. To achieve the research objectives and to collect research data, the Focus Group Discussion (FGD) was conducted. The FGD participants were 40 selected MSMEs companies under the guidance of the Padang City Cooperative and UMKM Official, which were determined purposively with the criteria of annual turnover of 500 million rupiah and owned at least 5 employees.

However, due to the Covid 19 pandemic conditions, which made the FGD unable to be implemented, the research team replaced it by designing an intellectual capital module to help participants understand and implement intellectual capital. In the module, it is explained that intellectual capital consists of 3 dimensions, namely; human capital, structural capital and customer capital. Referring to the research results of [7] there are 22 items/sub indicators in total forming the intellectual capital model for MSMEs in Padang City.

In distributing questionnaires and modules, the research team was assisted by an enumerator (data collection team). Prior to distributing the questionnaires, the research team equipped the data collection team with the procedure to distribute questionnaires to respondents, such as; provide a brief explanation of the contents of the intellectual capital module, and the benefits and objectives of the intellectual capital module. Then, each respondents will be distributed with the initial questionnaire, module and final questionnaire by the data collection team. Initial questionnaires and final questionnaires were distributed to respondents with the aim of measuring whether there was an increase in respondents' knowledge and understanding of the concept of intellectual capital in MSMEs, after the provision of the intellectual capital module. Modules will be handed to respondents and given a minimum of 3 days for respondents, to ask for comments and criticisms regarding the intellectual capital through questionnaires and a list of questions, both open and closed. It is expected that this module will enrich and strengthen the intellectual capital model that has been generated.

After the data is collected, it will then be analyzed quantitatively and qualitatively. Quantitative analysis is carried out by conducting different tests through ANOVA, with the aim of knowing whether there is an 
increase in the respondent's knowledge of the concept of the intellectual capital model of MSME, before and after the provision of the intellectual capital module. Meanwhile, qualitative descriptive analysis was carried out by collecting and analyzing the respondents' answers based on open and closed questions contained in the module.

\section{RESULTS AND DISCUSSION}

After determining the respondents, the research process begins by distributing the initial questionnaire without modules to the respondents. The distribution of the initial questionnaire aims to find out how well the respondents' understanding and knowledge of the concept of the intellectual capital model of MSMEs. After the initial questionnaire has been collected, the data collection team will provide the intellectual capital module along with the final questionnaire. The team will give the respondent a minimum of 3 days to ask for comments and criticisms in regards with intellectual capital through a questionnaire and a list of questions, both open and closed. With such process, it is expected that the research team will be able to measure both the initial knowledge and final knowledge of respondents concerning the concept of the intellectual capital model of MSMEs, especially for the city of Padang.

After the data was collected, it was analyzed quantitatively and qualitatively. Quantitative analysis is carried out using different test analysis through ANOVA, to determine whether there is an increase in the respondent's knowledge of the concept of the intellectual capital model of MSMEs, before and after the distribution of the intellectual capital module. While the qualitative analysis is carried out in a descriptive qualitative manner which aims to enrich and strengthen the model that has been generated.

\subsection{Quantitative Analysis Results}

As in the previous explanation, quantitative data analysis was carried out by performing a difference test through ANOVA. Before explaining the results of the Difference Test (ANOVA), the following table shows the characteristics of the research respondents, which amounted to 40 people.

From the description of respondents on table 3 , it can be inferred that the respondents in this study are made up from various characteristics. For example, the gender characteristics were dominated by men as many as 22 people and women as many as 18 respondents, concluded that there is no significant difference in the gender characteristics in the ownership of MSMEs. This occurred since both men and women can become MSME owners depending on capital and motivation in entrepreneurship. The second characteristic is the age of the respondent, which are dominated by 12 people aged
31-35 years. This implies that most respondents are business owners who are in their productive age in running a business. While the characteristics of the respondent's educational background were dominated by the 17 people with 3 -year diploma background. This identifies that MSME owners in the city of Padang have already possessed knowledge in the field of MSMEs. For the characteristic of length of business, it is dominated by business aged 6-10 years, as many as 16 businesses. This shows that the majority of MSMEs respondents are quite resilient in running their businesses, that the businesses they run would survive and have a longevity.

Table 3. Description of respondents

\begin{tabular}{|c|c|c|c|}
\hline No. & $\begin{array}{c}\text { Description of } \\
\text { Respondents }\end{array}$ & Item & $\begin{array}{c}\text { Number } \\
\text { of people }\end{array}$ \\
\hline \multirow{4}{*}{ Gender } & Male & 18 \\
& & Female & 22 \\
\hline \multirow{5}{*}{ Age } & 25-30 years & 3 \\
& & $31-35$ Years & 8 \\
& & $36-40$ Years & 7 \\
& & $>40$ Years & 10 \\
\hline \multirow{5}{*}{ Educational } & Elementary & - \\
& background & School & - \\
& & Hinior High school & 12 \\
& & D3 & 17 \\
& & S1 & 11 \\
& & S2 & - \\
\hline \multirow{6}{*}{} & & 15 years & 14 \\
& & $6-10$ Years & 16 \\
& Length of Business & $11-15$ years & 10 \\
& & $16-20$ years & - \\
& & $>20$ Years & - \\
\hline
\end{tabular}

After the initial questionnaire, intellectual capital module and final questionnaire have been collected, the next stage is a Difference Test through ANOVA. By conducting t-test related samples through the SPSS program, the following analysis results were obtained;

Table 4. Paired Sample Statistics

\begin{tabular}{|c|l|c|c|c|c|}
\hline \multicolumn{5}{|c|}{ Paired Samples Statistics } \\
\hline \multicolumn{2}{|c|}{} & Mean & N & $\begin{array}{c}\text { Std. } \\
\text { Deviation }\end{array}$ & $\begin{array}{c}\text { Std. Mean } \\
\text { Error }\end{array}$ \\
\hline $\begin{array}{c}\text { Pair } \\
1\end{array}$ & $\begin{array}{l}\text { before the } \\
\text { module handed }\end{array}$ & 54.8750 & 40 & 13,79741 & 2.18156 \\
\cline { 2 - 6 } & $\begin{array}{l}\text { after the module } \\
\text { handed }\end{array}$ & 81.3750 & 40 & 11.37854 & 1.79911 \\
\hline
\end{tabular}

Referring to table 4 above, it can be seen that the number of respondents were 40 people. Then the average knowledge of respondents concerning the concept of the intellectual capital of MSME before being given the intellectual capital module is; 54.8750 . Meanwhile, the average level of respondent's knowledge about the concept of the intellectual capital of MSME after being given the intellectual capital module was 
81.3750. Since the average knowledge of respondents before modules were distributed is smaller than the average knowledge of respondents after modules were distributed $(54.8750<81.375)$, descriptively there are differences in respondents' knowledge regarding the concept of MSME intellectual capital models before and after handed the module. There is a tendency in the increase of respondent's knowledge after being given the intellectual capital module.

Table 5. Paired Samples Test

\begin{tabular}{|c|c|c|c|c|c|c|c|c|c|}
\hline \multicolumn{10}{|c|}{ Paired Samples Test } \\
\hline & & \multicolumn{5}{|c|}{ Paired Differences } & \multirow[b]{3}{*}{$\mathrm{t}$} & \multirow[b]{3}{*}{ df } & $\begin{array}{l}\text { Sig } \\
\dot{(2-} \\
\text { tail } \\
\text { ed) }\end{array}$ \\
\hline & & \multirow{2}{*}{\multicolumn{2}{|c|}{$\begin{array}{l}\text { Std. } \\
\text { Devi } \\
\text { ation }\end{array}$}} & \multirow{2}{*}{$\begin{array}{c}\text { Std. } \\
\text { Mea } \\
n \\
\text { Error }\end{array}$} & \multicolumn{2}{|c|}{$\begin{array}{c}95 \% \\
\text { Confidence } \\
\text { Interval of } \\
\text { the } \\
\text { Difference }\end{array}$} & & & \\
\hline & & & & & $\begin{array}{l}\text { Low } \\
\text { er }\end{array}$ & $\begin{array}{c}\text { Uppe } \\
\text { r }\end{array}$ & & & \\
\hline Pair & before & - & 19.0 & 3.00 & - & - & - & 3 & .00 \\
\hline 1 & $\begin{array}{l}\text { being } \\
\text { given a } \\
\text { module } \\
\text { - after } \\
\text { being } \\
\text { given a } \\
\text { module }\end{array}$ & $\begin{array}{r}26,50 \\
000\end{array}$ & 2091 & 747 & $\begin{array}{r}32.5 \\
8318\end{array}$ & $\begin{array}{r}20.4 \\
1682\end{array}$ & $\begin{array}{r}8,8 \\
11\end{array}$ & 9 & 0 \\
\hline
\end{tabular}

Based on table 5 above, it shows that the sig. (2tailed) $0.000<0.05$, meaning that the average respondent's knowledge of the concept of intellectual capital before and after being given the intellectual capital module has a significant difference, with an average difference of -26.50 . This indicates that the provision of intellectual capital modules has a significant effect on increasing respondents' knowledge of the concept of intellectual capital for MSME, especially in Padang City.

\subsection{Results of Qualitative Descriptive Analysis}

The population in this study were all MSME entrepreneurs who were under the guidance of the Padang City Cooperative and UMKM Service in 2020 amounting to 11,700 MSME. The research respondents were determined by purposive sampling, with criteria of; annual turnover of 500 million rupiah and owns at least 5 employees. Accordingly, found as many as 40 MSME entrepreneurs as the respondents in the city of Padang. Respondents own various business fields. The description of the respondent's line of business can be seen in the following table;
Table 6. Characteristics of Respondents' Business Fields

\begin{tabular}{|l|l|c|}
\hline No. & \multicolumn{1}{|c|}{ Business fields } & $\begin{array}{c}\text { Number of } \\
\text { Respondents }\end{array}$ \\
\hline 1. & Food Culinary & 18 \\
\hline 2. & Retail & 5 \\
\hline 3. & Wedding property rental & 3 \\
\hline 4. & Barbershop & 2 \\
\hline 5. & Coffee Shop & 8 \\
\hline 6. & Laundry & 2 \\
\hline 7. & $\begin{array}{l}\text { Packaged culinary (Cake and } \\
\text { Pastry) }\end{array}$ \\
\hline \multicolumn{2}{|c|}{ Total Respondents } & 2 \\
\hline
\end{tabular}

In order to improve respondents' understanding regarding the concept of the intellectual capital model of MSME, the intellectual capital modules were distributed to respondents. The module is designed with reference to the research results of [7]. From the results of these studies, MSMEs intellectual capital model were formulated. The model consists of 3 dimensions, namely human capital, which can be well explained by the 7 statement items/sub indicators. Then there are 3 statement items or sub indicators that can measure the dimensions of customer capital and finally the dimension of structural capital, which can be measured by 12 statement items/sub indicators. In conclusion, there are 22 statement items/sub indicators in total that form the intellectual capital model for MSME, especially in Padang City. Each sub indicator module is equipped with several critical questions with the aim of obtaining responses and criticisms of how respondents implement the concept of the intellectual capital model in their business. Following is explained the respondent's answers related to some critical questions in the module.

Human capital represented by the knowledge and skills possessed by employees individually or personally. When employees exit or leave the company, the knowledge and skills will also leave the company. Therefore, retaining employees is an important factor for the company to run its operations swiftly. Referring to the research results of [7], the sub-indicators that are relatively important for the dimensions of human capital in MSMEs, especially in the city of Padang are: employee training, recruitment costs, competence in production, education level, teamwork, employees' motivation and employees' loyalty.

Training can be defined as an activity or program aims at increasing the knowledge and skills of employees needed in completing tasks for maximum results. Based on the respondents' answers, it is known 
that they constantly conduct training, especially for newly recruited employees. The knowledge and skills need to be trained are related to tasks in accordance with their respective fields of business, such as; skills in baristas, processing various dishes into innovative menus, knowledge of hairstyles, ability to provide services to consumers and ability to promote and increase sales. Respondents stated that the training was carried out independently through mentoring,

It is important for the respondents to conduct training, since the competence of employees is vastly limited. The majority of respondents hire employees with a secondary education level and above (SMA / SMK) without work experience. In fact, 30 respondents stated that they do not attach importance to the formal education of their employees, as the abilities and skills of employees can be trained and honed during the work process. Then the recruitment process is also carried out in simple and concise stages, starting from the process of receiving applications, file selection and interviews. There are even some respondents who hire employees based on recommendations from their families and also employees who have worked without a selection process.

Although the competence of the respondents' employees is limited, yet they are loyal employees. As stated by the majority of respondents, the turnover rate of their employees in the company is low. The majority of respondents motivate employees to stay with the company through financial motivation, by providing incentives or bonuses at the end of the month and an increase in salary. In addition, there are respondents who motivate employees through non-financial motivation, such as; creating employee comfort at work and bringing a conducive work environment. Although the work environment has been attempted to be as conducive as possible, still there is no clear work team formation model for the respondent's company. As it was stated by the respondents, their employees work individually, even uncoordinated, that it highly affect the service given to consumers.

Referring to the respondent's answer to critical questions related to the human capital dimension, it can be seen that the implementation of the concept of the MSME intellectual capital model is still limited, one of which is due to the limited competency of the respondent's employees. Although the majority of respondents already have Diploma (D3) and Bachelor (S1) education levels, the majority of their employees held Senior High degree (SMA/SMK) without work experience, as it is curtained that their knowledge of the concept of intellectual capital is likewise limited. For most employees, company is only a place to work to obtain income that their life needs are fulfilled.

Structural capital is a mechanisms and structures owned by the organization, thus, employees could optimally elaborate their individual human capital, in order to achieve high individual work performance as an effort to achieve the best organizational performance [3]. Based on the research results of [7] the relatively crucial sub indicator for the structural capital dimension in MSME in the city of Padang are; employees share knowledge within the company, the use of IT systems in the company, increasing the quality of products/services as well as improving them, maintaining the quality of product or service, increasing the company revenue, implementing new ideas on products or services, supporting employee creativity, system convenience, consideration of implementing new product/service ideas, increasing company turnover and business prospects.

Structural capital generally relates to the infrastructure owned by the company allowing the company to function optimally. One such infrastructure is the use of Information Technology (IT) systems in company operations, such as processing data into relevant information to support leadership decision making. Another principal part is the use of IT systems in managing and sharing employee knowledge within the company. Since the tacit knowledge that employees possessed before entering the organization and during the work process would disappear when the employee leaves the organization.

Based on respondents' answers to several critical questions related to the use of IT systems, it is known that nearly all respondents stated that they do not have a database and use IT systems in the decision-making process. In fact, they also do not have a knowledge management system (KMS) in managing employee knowledge. It is concluded that the knowledge owned by employees are still tacit knowledge it could not be shared with other employees. This occurred since the respondents of MSME entrepreneur own limited capital (asset) and even the competence of their employees is fairly limited. However, the respondents have basically used the IT system, yet it is still in a basic and simple form, such as utilizing the go food and go send features in the process of getting orders online. Then some respondents stated that they used social media such as Facebook and Instagram as promotional media to attract as many consumers as possible.

However, the majority of respondents already have concerns on improving the quality of the products or services they offer. Various means have been made to improve the quality of products/services, such as: consistently maintaining the taste of the food menu of the culinary business, always maintaining the quality of the raw materials used and as well as consistently maintaining the quality of service to consumers. Some respondents even specifically budgeted funds to create new product/service ideas. New product ideas are materialized from the varied menus offered by the 
respondent's culinary, coffee shop and packaged culinary businesses. Implementing new product and service ideas by respondents once in 6 months or even once in 3 months is one of the respondents' efforts to increase their business turnover. The implementation of new product and service ideas is also managed as an attempt for consumers to not get bored easily with the existing product variations.

The construct of structural capital is represented by the level of efficiency, standard operating procedures (SOP), innovation behavior, models of decision making and risk taking, as well as the resulting codes in the form of organizational climate, technology adoption and organizational communication systems. On that account, based on the respondent's answer, it is noted that the respondent has not represented the structural capital construct optimally, like not adopting information technology in decision making and employee knowledge management processes yet. However, support for employee innovation behavior has already exist as a means to uplift the implementation of new product and service ideas.

Customer capital refers to the company's strength to succeed that lies in the hands of consumers, which the company must be able to accumulate, maintain and create. Customer capital is manifested in the form of partnerships characterized by a long-term perspective, determination, honesty, accuracy, flexibility, and tolerance, [19]. The sub indicators of measuring the dimensions of customer capital are; consumer satisfaction, understanding of consumer needs and meeting consumer needs, [7].

Consumer satisfaction is the company's long-term asset in the consumer. Satisfaction can be defined as the feelings and imagination of customers towards certain products or brands which are represented through their attitudes and behaviors, [20]. Respondents realize that customer satisfaction does not come automatically, but it needs to be pursued by the company. There are several actions taken by respondents to increase customer satisfaction and loyalty, includes; providing the best service to consumers, maintaining and improving the consistency of the flavor of culinary products, providing a comfortable place to eat and offering discounts to consumers.

Consumers are a guarantee of the company's cash flow in the future and will determine the sustainability of the business or company. Meeting consumer needs is the key to increasing consumer loyalty. Consequently, it is necessary for the company to be able to find out what consumers need, what determines consumers to decide to buy the company's products. Respondents has realized the importance of the existence of consumers for the continuity of their business. Therefore, they constantly try to meet the needs of their consumers by offering a variety of products or services along with the best service to their customers. Thus, basically the respondents have realized the importance of maintaining long-term relationships with consumers in order to create loyal consumers. As the signs of loyal customers, among others, make repeated purchases, recommend to others, provide input to the company.

\subsection{Discussion}

Quantitative research result through difference test (ANOVA) showing the average knowledge of respondents regarding the concept of the intellectual capital of MSMEs before and after being given the intellectual capital module is a significant difference with the sig value. $0.000<0.05$. This indicates that the provision of intellectual capital modules has a significant effect on increasing respondents' knowledge of the concept of intellectual capital for MSMEs, especially in Padang City. Thus, it can be inferred that through the provision of intellectual capital modules, it can enrich the knowledge of MSMEs entrepreneur, especially in Padang City, to be able to understand the concept of intellectual capital models. In the end, with an increase in the knowledge of MSMEs players concerning the concept of the intellectual capital of MSMEs, it is expected that they are able to implement the concept of intellectual capital in their businesses, with the prospect of improving the performance of their business. As several studies have proven that the implementation of intellectual capital can increase the performance of SMEs, according to the results of research by [5], it is known that intellectual capital in MSME can contribute to the product innovation process leads to the increase of MSMEs performance. In line with [6], in general, it is stated that intellectual capital has a positive impact on the performance of MSME.

It is undeniable that in order to be able to implement the concept of the intellectual capital model of MSME, MSME entrepreneurs should have knowledge of these concepts. Moreover, employees have a key role in implementing the concept of intellectual capital. As stated by [15] the term intellectual capital refers to all non-tangible or non-physical assets and resources of an organization, including processes, innovation capacity, patterns and invisible knowledge of its members and collaboration networks and organizational relationships. Build upon the results of the study, it is discovered that the competence of MSME employees in the city of Padang is limited, where the majority of MSME employ high school/vocational school graduates without qualified work experience. Therefore, in order to increase the knowledge and innovation abilities of employees, it is necessary to continuously train employees, since training aims at increasing the knowledge and skills of employees needed in completing tasks for maximum results. 
As stated by [11] knowledge is related to information a person has for a particular field. Knowledge is a complex competency and is a crucial domain in shaping one's actions (Overt behavior). The results of the research prove that behavior based on knowledge will be more lasting than behavior that is not based on knowledge, for the knowledge that is owned will help improving performance through the completion of each task, [11].

[16] equalized intellectual capital as the sum of human capital and structural capital. Thus, it can be concluded that intellectual capital is the sum of what is produced by the three main elements of the organization (human capital, structural capital, customer capital) relating to knowledge and technology that is able to provide added value to the company for competitive advantage. Therefore, apart from maximizing the implementation of human capital in MSME, it needs to be supported by a mechanism and structure owned by the organization that employees could optimally elaborate their individual human capital, in order to achieve high individual work performance in an effort to achieve the best performance of the organization, [18].

Structural capital In general relates to the infrastructure owned by the company allowing the company to function optimally and to adapt to any changes that occurred, [17]. One such infrastructure is the use of Information Technology (IT) systems in company operations, [7]. Thus, based on respondents' answers, it is known that MSME entrepreneurs in the city of Padang have not been optimally adopting the information technology in decision making and in the process of managing employee knowledge. Therefore, it is necessary to make consistent efforts from MSME entrepreneurs to optimize the use of Information Technology (IT) systems, that employees can optimally elaborate their individual human capital, in order to deliver high performance. Through the implementation of IT systems, it is expected that it can support employee innovation behavior as an effort to increase the implementation of new product and service ideas. MSME entrepreneurs in Padang City realize the importance of implementing new product and service ideas in maintaining and improving the quality of products or services to consumers.

Consumers are a guarantee of the company's cash flow in the future and will determine the sustainability of the business or company. Customer satisfaction is an important factor in realizing consumer loyalty, [7]. Various attempts can be made to increase customer satisfaction, including improving product quality, improving service quality to consumers, and finally trying to understand and meet consumer needs. MSMEs entrepreneurs in the city of Padang have realized the importance of increasing consumer satisfaction, since it is consumers who ensure the continuity of their business in the future. Because when consumers are loyal to a company, they will make repeated purchases, recommend to others, provide input to the company.

\section{CONCLUSION}

Out of the research results, it can be concluded that the average knowledge of respondents in regards with the concept of the intellectual capital of MSMEs before and after being given the intellectual capital module is a significant difference with the sig value. $0.000<0.05$. This shows that there is a significant effect of the provision of intellectual capital modules on increasing the respondent's knowledge of the concept of the intellectual capital model of MSMEs, especially in Padang City.

Intellectual capital is the sum of what is generated by the three main elements of the organization (human capital, structural capital, customer capital) relating to knowledge and technology providing added value to the company for competitive advantage. Based on the results of research analyzed from critical questions in the intellectual capital module, it is known that the implementation of the three dimensions of the concept of the intellectual capital of MSMEs by MSMEs entrepreneurs in Padang City has not been running optimally, especially in the dimensions of human capital and structural capital. The lack of optimal implementation of the human capital dimension by MSMEs entrepreneurs in the city of Padang is affected by the limited competency of their employees, the majority of which are only high school/vocational graduates without qualified work experience. Furthermore, due to the limited financial capacity of MSMEs. entrepreneurs in the city of Padang, the use of information technology systems is not optimal to support company operations, since one of the infrastructures form structural capital in companies is the use of Information Technology (IT) systems.

\section{ACKNOWLEDGMENTS}

We would like to show our gratitude to Universitas Negeri Padang for funding this research.

\section{REFERENCES}

[1] T.A. Stewart, Intellectual Capital (Modal Intelektual): Kekayaan Baru Organisasi. Jakarta: PT Elex Media Komputindo. 2002.

[2] T. Sawarjuwono \& A.P. Kadir. Intellectual Capital: Perlakuan, Pengukuran dan Pelaporan (sebuah library research). Jurnal Akuntansi\&Keuangan Vol.5, No. 1. pp; 35-57. 2003. 
[3] N.K. Bontis, Intellectual Capital: an exploratory study that develops measures and models. Management Decision, Vol.3 No.36, pp 63-76. 1998.

[4] C.C. Huang, R. Luther, \& M. Tayles, An Evidancebased Taxonomy of Intellectual Capital. Journal of Intellectual Capital. Vol. 8, No.3. pp 386-408. 2007.

[5] R. Ngah, \& A.B. Ibrahim, The Relationship of Intellectual Capital, Innovation and Organizational Performance: Preliminary Study In Malaysian SMEs. International Journal of management Innovation Systems. Vol.1, No. 1. ISSN 1943-1384. pp 1-13. 2009.

[6] A. Daou, E. Karuranga, \& S. Zhan, Intellectual Capital In Mexican SMEs From the Pespective Of The Resource-Based And Dynamic Capabilities Views. The Journal of Applied Business Research, Vol.29 No.6, pp 1673-1688. 2013.

[7] Sulastri, Y. Fitria \& C. Andriani. Exploration Of Dimensions And Measurements In Intellectual Capital Modeling. Proceeding The 4th Padang International Conferences on Education, Economics, Business, and Accounting. Atalantis-Press. 2019.

[8] L.R. Mathis, dan H.J. Jackson, Manajemen Sumber Daya Manusia. Jakarta : Salemba Empat. 2001.

[9] W.A. Surya, E.S. Astuti \& H. Susilo, Pengaruh Employee Knowledge, Skill, dan Ability (KSA) terhadap Penggunaan Sistem Informasi Sumberdaya Manusia dan Kinerja Karyawan. Jurnal Administrasi Bisnis (JAB). Vol. 8 No. 1. Pp; 1-7. 2014.

[10] Y. Suhartini, Pengaruh Pengetahuan, Keterampilan dan Kemampuan Karyawan terhadap Kinerja Karyawan (Studi pada Industri Kerajinan Kulit di Manding, Bantul, Yogyakarta). Akmenika Jurnal Akunatansi dan Manajemen. Vol. 12. No.2. 2015.

[11] Alias \& S. Serang, Pengaruh Pengetahuan, Sikap Kerja dan Pengalaman Kerja terhadap Kinerja Karyawan. Paradoks Jurnal Ilmu Ekonomi. Vol.1 No.1. pp; 82-97. 2018.

[12] R.A. Noe, et. Al, Human Resource Management, Gaining Competitive Advantage $3^{\text {rd }}$ Edition. McGraw-Hill. 2012.

[13] Sulastri, Pengaruh Intellectual Capital dan Social Capital terhadap Kompensasi Karyawan dan Kinerja Perusahaan. Proceding International Seminar Empowering Economic \& Business in Free Trade Era. Fakultas Ekonomi Universitas Muhammadiyah Surakarta. 2005.

[14] Sulastri, C. Andriani \& Y. Fitria, The Implementation Analysis Of Intellectual Capital To Departement Performance In Padang State University. Asia Pacific Management Business Aplication 3(1) pp 1-13. DOI: http://dx.doi.org/10.21776/ub.apmba.2014.003.01.1. 2014

[15]J. Guthrie, Intellectual Capital: Australian Annual Reporting Practices. Journal of Intellectual Capital, 241. 2000.

[16] B. Brinker, Intellectual capital: tomorrow's assets, today's challeng, available at: www.cpavision.org/vision/wpaper0b.cfm. 1997.

[17] Sulastri, Manajemen Perubahan. Padang: Sukabina Press. 2018.

[18] N. Bontis, Assessing Knowledge Assets: A Review of the Models Used to Measure Intellectual Capital. International Journal of Management Reviews. Vol. 3. No.1. 2001.

[19] G. Ciemleja, \& N. Lace, The Factors Determining Innovation-Based Attitute of Lavtian SMEs Towards Sustainability. $5^{\text {th }}$ International Scientific Conference Business and Management. Pp; 31-39. 2008.

[20] A.S. abu-alhaija, H.Hashim, R. Nerina, N.S. Jaharuddin, Determinants of Customer Loyalty: A review and Future direction. Austraian Journal of Basic and Applied Sciences, 12(7): 106-111. 2018. 